\title{
Concurrent diabetic ketoacidosis and pancreatitis in Paediatric acute lymphoblastic leukemia receiving L- asparaginase
}

\author{
Patel Zeeshan Jameel ${ }^{1 *}$ (D, Sham Lohiya', Amol Dongre ${ }^{2}$, Sachin Damke ${ }^{1}$ and Bhavana B. Lakhkar ${ }^{1}$
}

\begin{abstract}
Background: Although hyperglycemia and pancreatitis are known side effects of L-asparaginase, both contributing to the development of diabetic ketoacidosis (DKA) is unfamiliar in literature.

Case presentation: We report a case of an adolescent girl, recently diagnosed with ALL, who presented with pain in abdomen and breathing difficulty following chemotherapy with L-asparaginase. On subsequent evaluation, she was found to have high anion gap metabolic acidosis, hyperglycemia and ketonuria. Ultrasonogram showed bulky pancreas. DKA was managed with fluid correction and insulin infusion. Pancreatitis was managed conservatively. She recovered completely with resolution of symptoms and without any major adverse events despite having such severe complications.

Conclusion: We conclude that the combination of DKA and pancreatitis is a rare occurrence with significant morbidity and mortality. We recommend a close monitoring of blood glucose levels for hyperglycemia as well as a high index of clinical suspicion for pancreatitis in patients with ALL receiving L-asparaginase.
\end{abstract}

Keywords: Diabetic ketoacidosis, Pancreatitis, L-asparaginase

\section{Background}

Acute lymphoblastic leukemia (ALL) accounts for approximately $77 \%$ cases of childhood leukemia [1]. In the year 2016, leukemia accounted for approximately 34,000 cases among all age groups in India [2]. The age-standardized incidence rate has declined sharply since 1990 by $16.1 \%$ but leukemia continues to be responsible for the highest proportion of the cancer DALYs (34.6\%) in India among the agegroup 0-14 years in the year 2016 [2]. The overall 5-year survival has increased to approximately $90 \%$ in the paediatric

\footnotetext{
*Correspondence: zeeshan1311@gmail.com

'Department of Paediatrics, Jawaharlal Nehru Medical College, Sawangi Meghe, Wardha, India

Full list of author information is available at the end of the article
}

age group as a result of improvements in chemotherapy and risk stratification [1].

L-asparaginase has been a mainstay of pediatric chemotherapy protocols to treat patients with ALL since its discovery by Kidd in 1953 [3]. Standard chemotherapy regimens involved the use of vincristine and prednisolone to induce the first remission in patients with ALL until the discovery of L-asparaginase. The earliest literature describing the use of $\mathrm{L}$-asparaginase in humans was reported in the mid-1960s by Dolowy et al. [4] and Hill et al. [5]. Treatment protocols with and without L-asparaginase have revealed that clinical outcomes were superior with those incorporating L-asparaginase [6]. Adverse effects of L-asparaginase include hypersensitivity reactions, including urticaria and anaphylaxis, thrombosis, hepatotoxicity,

C C The Author(s). 2020 Open Access This article is licensed under a Creative Commons Attribution 4.0 International License, which permits use, sharing, adaptation, distribution and reproduction in any medium or format, as long as you give appropriate credit to the original author(s) and the source, provide a link to the Creative Commons licence, and indicate if changes were made. The images or other third party material in this article are included in the article's Creative Commons licence, unless indicated otherwise in a credit line to the material. If material is not included in the article's Creative Commons licence and your intended use is not permitted by statutory regulation or exceeds the permitted use, you will need to obtain permission directly from the copyright holder. To view a copy of this licence, visit http://creativecommons.org/licenses/by/4.0/ The Creative Commons Public Domain Dedication waiver (http://creativecommons.org/publicdomain/zero/1.0/) applies to the data made available in this article, unless otherwise stated in a credit line to the data. 
hypertriglyceridemia, hypoalbuminemia, intracranial hemorrhage, encephalopathy, myelosuppression, hyperglycemia, pancreatitis, and rarely diabetic ketoacidosis (DKA) [7-9].

Although, all of the above mentioned are known complications, DKA with pancreatitis in an adolescent receiving L-asparaginase presents a rare occurrence.

\section{Case presentation}

A 14 year old adolescent female, belonging to central India, was diagnosed with B- cell ALL and started on induction phase of chemotherapy with Vincristine (1.5 $\mathrm{mg} / \mathrm{m}^{2}$; once weekly), Prednisolone $\left(60 \mathrm{mg} / \mathrm{m}^{2} /\right.$ day $)$, Daunomycin $\left(30 \mathrm{mg} / \mathrm{m}^{2}\right.$; once weekly), intrathecal Methotrexate (12 mg; once weekly) and Non-pegylated L-asparaginase $\left(10,000 \mathrm{IU} / \mathrm{m}^{2}\right.$; on day $6,9,12,15,18$ of induction phase). On the 21st day of the induction phase, patient complained of abdominal pain and breathlessness. Examination revealed tachycardia $(150 / \mathrm{min})$, tachypnea (40/min), a low volume, thready pulse and hypotension (BP-80/50 mmHg). She had cold extremities and signs of dehydration.

Investigations showed a blood sugar level of $501 \mathrm{mg} /$ dl. Venous blood gas showed a $\mathrm{pH}$ of 7.22, $\mathrm{pCO}_{2}$ of $15.8 \mathrm{mmHg}, \mathrm{HCO}_{3}$ of $10.4 \mathrm{mmol} / \mathrm{L}$, serum sodium of $138 \mathrm{mEq} / \mathrm{L}$, serum potassium of $3.6 \mathrm{mEq} / \mathrm{L}$, serum chloride of $110 \mathrm{mEq} / \mathrm{L}$ (Anion gap: 17.6). Urinary ketone bodies were positive (moderate size- $40 \mathrm{mg} / \mathrm{dl}$ ). Further investigations showed, glycosylated $\mathrm{HbA}_{1} \mathrm{C}$ was $7.95 \%$, serum amylase $479 \mathrm{IU} / \mathrm{L}$ and serum lipase $3340 \mathrm{IU} / \mathrm{L}$. Liver enzymes and renal function tests were within normal limits. A sonogram of the abdomen showed bulky pancreas with normal echotexture (Fig. 1). To summarize, our patient had high anion gap metabolic acidosis, ketonuria and elevated levels of $\mathrm{HbA}_{1} \mathrm{C}$, serum lipase and amylase with bulky pancreas on imaging. Based on above findings, a diagnosis of moderate DKA with acute pancreatitis was made.

She was managed with fluid resuscitation, insulin infusion in accordance with International Society for Pediatric and Adolescent Diabetes (ISPAD) 2018 regimen for DKA. Acute pancreatitis was managed conservatively. Metabolic acidosis resolved over the next $36 \mathrm{~h}$ following which insulin infusion was replaced by subcutaneous regular insulin, with the requirement of insulin being very low $(0.15 \mathrm{IU} / \mathrm{Kg} /$ day $)$. As this metabolic state was drug-induced and transient, she was continued on regular insulin till normalization of blood sugars. She was discharged with no further complications.

On follow-up, she is maintaining normal blood sugars without requiring insulin for the last few weeks. Further plan includes a bone marrow examination and continuation of chemotherapy excluding L-asparaginase.

\section{Discussion and conclusion}

The present case constitutes a rare combination of DKA and pancreatitis, secondary to the use of L-asparaginase based chemotherapy during the induction phase.

The risk, among children receiving chemotherapy for ALL, of developing infections, hyperglycemia (attributable to the use of L-asparaginase and prednisolone), pancreatitis and the leukemic process itself is about 10$15 \%$ [10]. Plourde et al. [11] and Pui et al. [12] found the incidence of $\mathrm{L}$-asparaginase use associated hyperglycemia to be 3.7 and $9.7 \%$ respectively. $\mathrm{L}$-asparaginase causes hyperglycemia by depletion of asparagine resulting in a decline of insulin production. In addition, $\beta$ cell dysfunction, caused due to pancreatitis, reduces insulin secretion from the beta cells of pancreas and hyperglucagonemia contribute to abnormal blood glucose levels

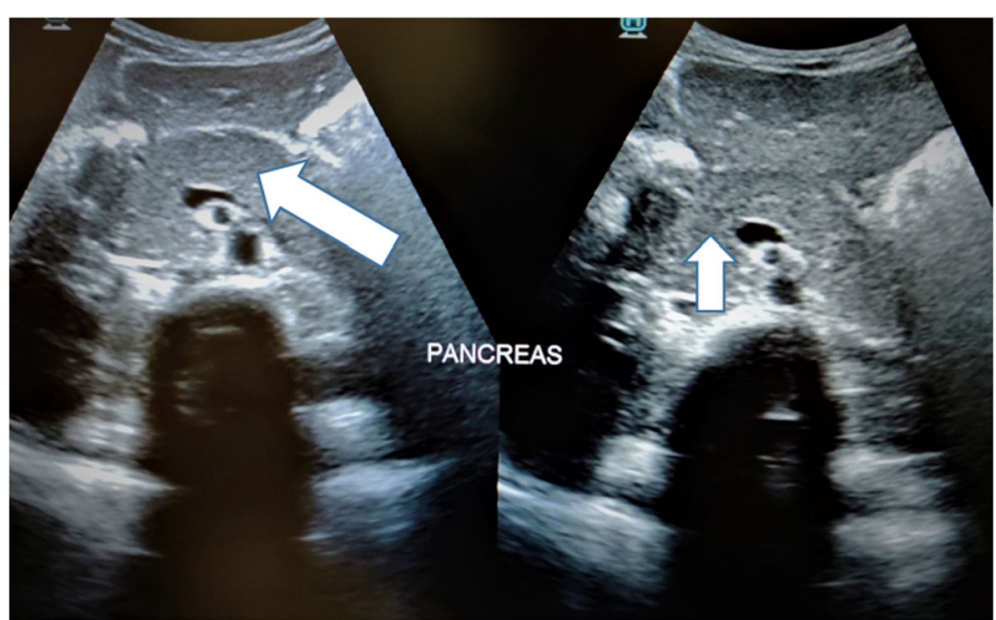

Fig. 1 Grey scale ultrasound image showing features suggestive of acute pancreatitis: slightly bulky and enlarged visualized part of pancreas appearing uniformly hypoechoic. Main pancreatic duct appears normal. Minimal fat stranding was also noted 
[10, 13-15]. Risk factors for hyperglycemia during ALL therapy include age $>10$ years, obesity, down's syndrome, use of prednisolone and/or L-asparaginase [12]. Two of the above-mentioned risk factors were present in our case as well. The risk of hyperglycemia rises with the concomitant use of L-asparaginase and prednisolone; however, these episodes tend to be self-limiting and subside with no further complications [16, 17]. Additionally, pancreatitis itself may be responsible for metabolic abnormalities such as hyperglycemia and diabetes mellitus.

Despite hyperglycemia being commonly associated with L-asparaginase, DKA is a rare occurrence with a reported prevalence varying from $0.75-2.3 \%[10,18,19]$. Cases in childhood have been reported of DKA in ALL associated with L-asparagianase [18-22]. There is no conclusive evidence on the time taken for diabetogenic effects of L-asparaginase [10]. In our case, the patient developed DKA on 16th day following the administration of first dose of the L-asparaginase in the induction phase. DKA is generally mild with short term morbidity but may lead to permanent sequelae. Wolthers et al. [23] described in their population-based Nordic Society of Paediatric Hematology and Oncology (NOPHO) 2008 ALL pancreatitis study that $8 \%(7 / 86)$ of children, who had developed pancreatitis during the course of treatment for ALL, required insulin therapy on follow-up.

The second complication encountered in our patient was acute pancreatitis. In a recent study evaluating children with ALL, the incidence of L-asparaginase induced pancreatitis was $6.8 \%(86 / 1285)$ [24] while other studies have reported from 2 to $18 \%$ [7, 25-27]. In spite of pancreatitis being a known complication of L-asparaginase, the exact pathogenesis is yet to be discovered. A possible mechanism could be that it decreases the protein synthesis due to systemic depletion of asparagine [28]. Multiple studies have shown the possible role of genes such as ULK2 and trypsin encoding PRSS1-PRSS2 [29, 30]. Although DKA causing elevation of pancreatic enzymes is a known entity, clinical pancreatitis is rare. Incidence of acute pancreatitis in children with DKA was reported to be $2 \%$ [31]. The mechanism by which DKA causes pancreatitis still remains elusive. It has been postulated that minor injury or inflammation in pancreas leads to leakage of pancreatic enzymes [32]. In addition, hyperlipidemia contributes to acute pancreatitis by build-up of degradation products from triglycerides due to the action of pancreatic lipases, which in turn are directly toxic to the acinar cells $[32,33]$. In a systematic review, it was concluded that older age, formulation of L-asparaginase, higher ALL risk stratification and a higher dosing of Lasparagine appear to raise the risk of pancreatitis in some studies [34]. In a retrospective cohort study by Treepongkaruna et al. [27], it was reported that pancreatitis developed after a median of 5.5 doses with a median interval of 4 days from the last dose of L-asparaginase therapy. Our patient showed signs of pancreatitis 2 days after receiving 5th dose. The clinical course of both complications can range from mild to severe disease. The mortality is significantly higher in ALL patients with acute pancreatitis (43.8\% Vs 19.3\%) [27].

There is a possibility that combined use of L-asparaginase and prednisolone along with L-asparaginase induced pancreatitis might have precipitated ketoacidosis in our patient. However, it is difficult to ascertain if the primary inciting event was pancreatitis or diabetic ketoacidosis. Prompt diagnosis and appropriate management of both DKA and pancreatitis were extremely crucial for the survival of our patient.

From this case we infer that DKA and pancreatitis occurring together in a patient with ALL on chemotherapy is rare but when it does occur, is associated with significant morbidity and mortality. In the absence of a consensus on the frequency of blood glucose monitoring, we recommend for a close follow-up of blood glucose levels for hyperglycemia as well as a high index of clinical suspicion for pancreatitis is essential in patients with ALL receiving $\mathrm{L}$-asparaginase.

\section{Learning points}

- Simple, minimally invasive blood tests such as blood glucose level can detect impaired glucose metabolism at an earlier stage, thus, preventing progression to complications such as DKA.

\section{Abbreviations}

ALL: Acute lymphoblastic leukemia; DKA: Diabetic ketoacidosis; ISPAD: International Society for Pediatric and Adolescent Diabetes; NOPHO: Nordic Society of Paediatric Hematology and Oncology; DALYs: Disability adjusted life year

\section{Acknowledgements}

Not applicable.

\section{Authors' information (optional) \\ Already included.}

\section{Authors' contributions}

SL was responsible for the considering this rare adverse event as a differential diagnosis. PZJ was a major contributor for writing this manuscript and patient care. AD was majorly involved in the chemotherapy management. SD was overlooking the patient's management and corrected the final manuscript. BBL critically reviewed the abstract section. All the authors have read and approved of the final manuscript.

\section{Funding \\ Not applicable.}

\section{Availability of data and materials \\ The datasets used and/or analysed during the current study are available from the corresponding author on reasonable request.}

Ethics approval and consent to participate

The authors certify that they have obtained all appropriate patient consent forms. In the form the patient's parents have given their consent for patient's images and other clinical information to be reported in the journal. The 
patient's parents understand that their names and initials will not be published and due efforts will be made to conceal their identity, but anonymity cannot be guaranteed.

\section{Consent for publication}

Written informed consent was obtained from the patient's parents for publication of this case report and any accompanying images and videos. A copy of the written consent is available for review by the Editor-in-Chief of this journal.

\section{Competing interests}

The authors declare that they have no competing interests.

\section{Author details}

${ }^{1}$ Department of Paediatrics, Jawaharlal Nehru Medical College, Sawangi Meghe, Wardha, India. ${ }^{2}$ Department of Oncology, Jawaharlal Nehru Medical College, Sawangi Meghe, Wardha, India.

Received: 23 January 2020 Accepted: 11 May 2020

Published online: 18 May 2020

\section{References}

1. Friehling E, Kim Ritchey A, Tubergen DG, Bleyer A. Acute lymphoblastic luekemia. In: Kleigman RM, St Geme III JW, Blum NJ, Tasker RC, Shah SS, Wilson KM, editors. Nelson textbook of pediatrics. 21st ed. Philadelphia: Elsevier; 2019. p. 2649-53.

2. Dhillon PK, Mathur P, Nandakumar A, Fitzmaurice C, Kumar GA, Mehrotra R, et al. The burden of cancers and their variations across the states of India: the global burden of disease study 1990-2016. Lancet Oncol. 2018;19(10): 1289-306.

3. Kidd JG. Regression of transplanted lymphomas induced in vivo by means of normal Guinea pig serum. I. Course of transplanted cancers of various kinds in mice and rats given Guinea pig serum, horse serum, or rabbit serum. J Exp Med. 1953;98(6):565-82.

4. Dolowy WC, Henson D, Cornet J, Sellin H. Toxic and antineoplastic effects of L-asparaginase. Study of mice with lymphoma and normal monkeys and report on a child with leukemia. Cancer. 1966;19(12):1813-9.

5. Hill JM, Roberts J, Loeb E, Khan A, MacLellan A, Hill RW. L-Asparaginase therapy for leukemia and other malignant neoplasms: remission in human leukemia. JAMA. 1967;202(9):882-8.

6. Pession A, Valsecchi MG, Masera G, Kamps WA, Magyarosy E, Rizzari C, et al. Long-term results of a randomized trial on extended use of high dose IAsparaginase for standard risk childhood acute lymphoblastic leukemia. J Clin Oncol. 2005:23(28):7161-7.

7. Sahu S, Saika S, Pai SK, Advani SH. L-asparaginase (Leunase) induced pancreatitis in childhood acute lymphoblastic leukemia. Pediatr Hematol Oncol. 1998;15(6):533-8.

8. Wellstein A, Glaccone G, Atkins M, Sausville E. Cytotoxic drugs. In: Brunton LL, Hilal-Dandan R, Knollmann BC, eds. The Pharmacological basis of therapeutics. 13th ed. New York: McGraw Hill Education; 2018. p. 1167-120.

9. Hijiya $\mathrm{N}$, van der Sluis IM. Asparaginase-associated toxicity in children with acute lymphoblastic leukemia. Leuk Lymphoma. 2016;57(4):748-57.

10. Roberson JR, Raju S, Shelso J, Pui C-H, Howard SC. Diabetic ketoacidosis during therapy for pediatric acute lymphoblastic leukemia. Pediatr Blood Cancer. 2008;50(6):1207-12

11. Plourde PV, Jeha S, Hijiya N, Keller FG, Silverman LB, Rheingold SR, et al. Safety profile of asparaginase Erwinia chrysanthemi in a large compassionate-use trial. Pediatr Blood Cancer. 2014;61(7):1232-8.

12. Pui $\mathrm{C}-\mathrm{H}$, Burghen GA, Bowman WP, Aur RJA. Risk factors for hyperglycemia in children with leukemia receiving I-asparaginase and prednisone. J Pediatr. 1981;99(1):46-50

13. Dacou-Voutetakis C, Palis J, Haidas S, Zannos-Mariolea L, Georgiopoulou P, Matsaniotis N. Abnormal glucose tolerance in children with acute leukemia. Effect of induction chemotherapy including L-asparaginase. Am J Pediatr Hematol Oncol. 1983:5(2):139-46.

14. Tosur M, Viau-Colindres J, Astudillo M, Redondo MJ, Lyons SK. Medicationinduced hyperglycemia: pediatric perspective. BMJ Open Diabetes Res Care. 2020;8(1):e000801

15. Hwangbo Y, Lee EK. Acute hyperglycemia associated with anti-Cancer medication. Endocrinol Metab. 2017;32(1):23-9.
16. Khan A, Adachi M, Hill JM. Potentiation of Diabetogenic effect of $L$ Asparaginase by prednisolone. Horm Metab Res. 1970;2(5):275-6.

17. Aisyi M, Andriastuti M, Kurniati N. The effect of combination of steroid and L-Asparaginase on hyperglycemia in children with acute lymphoblastic leukemia (ALL). Asian Pac J Cancer Prev. 2019;20(9):2619-24.

18. Mondal R, Nandi M, Tiwari A, Chakravorti S. Diabetic ketoacidosis with Lasparaginase therapy. Indian Pediatr. 2011;48(9):735-6.

19. Cetin M, Yetgin S, Kara A, Tuncer AM, Günay M, Gümrük F, et al. Hyperglycemia, ketoacidosis and other complications of L-asparaginase in children with acute lymphoblastic leukemia. J Med. 1994;25(3-4):219-29.

20. Baillargeon J, Langevin A-M, Mullins J, Ferry RJ, DeAngulo G, Thomas PJ, et al. Transient hyperglycemia in Hispanic children with acute lymphoblastic leukemia. Pediatr Blood Cancer. 2005;45(7):960-3.

21. Quintanilla-Flores DL, Flores-Caballero MÁ, Rodríguez-Gutiérrez R, TamezPérez HE, González-González JG. Acute Pancreatitis and Diabetic Ketoacidosis following L-Asparaginase/Prednisone Therapy in Acute Lymphoblastic Leukemia. Case Rep Oncol Med. 2014; Available from: https://www.hindawi.com/journals/crionm/2014/139169/abs/.[cited 2019 Oct 30].

22. Gifford G, Milliken S, Greenfield J. Diabetic ketoacidosis secondary to Lasparaginase in acute lymphoblastic leukaemia. Intern Med J. 2013;43(8): 946-8.

23. Wolthers BO, Mogensen PR, Frandsen TL, Abrahamsson J, Behrendtz M, Heyman M, et al. Insulin-dependent diabetes: a chronic complication to acute pancreatitis in childhood acute lymphoblastic leukemia. Pediatr Blood Cancer. 2019;66(1):e27437.

24. Wolthers BO, Frandsen TL, Abrahamsson J, Albertsen BK, Helt LR, Heyman $M$, et al. Asparaginase-associated pancreatitis: a study on phenotype and genotype in the NOPHO ALL2008 protocol. Leukemia. 2017;31(2):325-32.

25. Alvarez OA, Zimmerman G. Pegaspargase-induced pancreatitis. Med Pediatr Oncol. 2000:34(3):200-5

26. Knoderer HM, Robarge J, Flockhart DA. Predicting asparaginase-associated pancreatitis. Pediatr Blood Cancer. 2007:49(5):634-9.

27. Treepongkaruna S, Thongpak N, Pakakasama S, Pienvichit P, Sirachainan N, Hongeng $\mathrm{S}$. Acute pancreatitis in children with acute lymphoblastic leukemia after chemotherapy. J Pediatr Hematol Oncol. 2009;31(11):812.

28. Raja RA, Schmiegelow K, Frandsen TL. Asparaginase-associated pancreatitis in children. Br J Haematol. 2012;159(1):18-27.

29. Wolthers BO, Frandsen TL, Patel CJ, Abaji R, Attarbaschi A, Barzilai S, et al. Trypsin-encoding PRSS1-PRSS2 variations influence the risk of asparaginaseassociated pancreatitis in children with acute lymphoblastic leukemia: a Ponte di Legno toxicity working group report. Haematologica. 2019;104(3): 556-63.

30. Wang J, Cheng S, Hu L, Huang T, Huang Z, Hu S. Association of asparaginase-associated pancreatitis and ULK2 gene polymorphism. Int J Clin Exp Pathol. 2020;13(3):347-56.

31. Haddad NG, Croffie JM, Eugster EA. Pancreatic enzyme elevations in children with diabetic ketoacidosis. J Pediatr. 2004;145(1):122-4.

32. Nair S, Yadav D, Pitchumoni CS. Association of diabetic ketoacidosis and acute pancreatitis: observations in 100 consecutive episodes of DKA. Am J Gastroenterol. 2000;95(10):2795-800.

33. Nagai $H$, Henrich $H$, Wünsch $P H$, Fischbach W, Mössner J. Role of pancreatic enzymes and their substrates in autodigestion of the pancreas. In vitro studies with isolated rat pancreatic acini. Gastroenterology. 1989;96(3):83847.

34. Oparaji J-A, Rose F, Okafor D, Howard A, Turner RL, Orabi Al, et al. Risk factors for Asparaginase-associated pancreatitis: a systematic review. J Clin Gastroenterol. 2017;51(10):907-13.

\section{Publisher's Note}

Springer Nature remains neutral with regard to jurisdictional claims in published maps and institutional affiliations. 